\title{
Weekly Docetaxel and Gemcitabine as First-Line Treatment for Metastatic Breast Cancer: Results of a Multicenter Phase II Study
}

\author{
S. Palmeri ${ }^{\mathrm{a}}$ M. Vaglica ${ }^{\mathrm{a}}$ \\ S. Spada ${ }^{b}$ \\ G. Filippellic \\ A. Farris ${ }^{d}$ \\ L. Palmeri ${ }^{\mathrm{a}}$ \\ B. Massidda ${ }^{\mathrm{e}}$ \\ A. Misino ${ }^{f}$ \\ F. Ferraù ${ }^{g}$ \\ G. Comella ${ }^{h}$ \\ V. Leonardi ${ }^{i}$ \\ G. Condemi \\ A. Mangiameli ${ }^{m}$ \\ G. De Cataldis ${ }^{n}$ \\ M.C. Macaluso a \\ M. Cajozzo ${ }^{\circ}$ \\ E. Iannitto ${ }^{a}$ \\ M. Danova ${ }^{p}$ \\ a Dipartimento di Oncologia, Cattedra di Oncologia Medica, Università di Palermo, Palermo, \\ ${ }^{\mathrm{b}}$ Oncologia Medica, AO Umberto I, Siracusa, ${ }^{\mathrm{C} O n c o l o g i a ~ M e d i c a, ~ P a o l a, ~}{ }^{\mathrm{d} C l i n i c a}$ Medica, Cattedra di Oncologia \\ Medica, Università di Sassari, Sassari, ${ }^{e}$ Cattedra di Oncologia Medica, Università di Cagliari, Cagliari, \\ ${ }^{f}$ Oncologia Medica, Istituto Oncologico di Bari, Bari, ${ }^{9}$ Oncologia Medica, Ospedale di Taormina, Taormina,

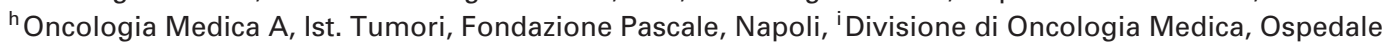 \\ Oncologico M. Ascoli, Palermo, 'Oncologia Medica, Lamezia Terme, 'm Unità Funzionale di Oncologia, Catania, \\ ${ }^{n}$ Oncologia, Ospedale G. da Procida, Salerno, ${ }^{\circ}$ Dipartimento di Chirurgia Generale, Università di Palermo, \\ Palermo, ${ }^{\mathrm{P}}$ Oncologia Medica, Università e IRCCS Policlinico S. Matteo, Pavia, Italia
}

\section{Key Words}

Docetaxel · Gemcitabine - Metastatic breast cancer •

Phase II study

\begin{abstract}
Objectives: We conducted a multicenter phase II study to evaluate the clinical efficacy, toxicity, and dose intensity of a new weekly schedule of docetaxel and gemcitabine as first-line treatment of metastatic breast cancer patients. Methods: We enrolled 58 patients, $52 \%$ of whom had received a previous anthracycline-containing chemotherapy. The treatment schedule was: docetaxel $35 \mathrm{mg} / \mathrm{m}^{2}$ and gemcitabine $800 \mathrm{mg} / \mathrm{m}^{2}$ i.v. on days 1, 8, 15 every 28 days. Results: All patients were assessable for toxicity and 56 for efficacy. Overall response rate was $64.3 \%$ with $16.1 \%$ of complete responses and $48.2 \%$ of partial responses. Median survival was 22.10 months (95\% Cl: 15.53-28.67) and median time to tumor progres-
\end{abstract}

sion was 13.6 months (95\% Cl: 10.71-16.49). The most common hematological toxicity was neutropenia (no febrile neutropenia), which occurred in 28 patients (48.3\%) but grade 3-4 in only 8 patients (14\%). Alopecia, the most common nonhematological toxicity, occurred in 20 $(34.5 \%)$ patients, but only 5 patients $(8.6 \%)$ experienced grade 3 alopecia. Conclusion: The activity of docetaxel and gemcitabine in metastatic breast cancer is confirmed. The promising results of the employed schedule, in agreement with other published studies, need to be further confirmed within a phase III study.

Copyright $@ 2005$ S. Karger AG, Basel

\section{Introduction}

The treatment of metastatic breast cancer (MBC), a typically incurable disease, is one of the main active research fields for medical oncologists. Between the 1970s

\section{KARGER \\ Fax +4161306 1234 E-Mailkarger@karger.ch} www.karger.com (c) 2005 S. Karger AG, Basel $0030-2414 / 05 / 0686-0438 \$ 22.00 / 0$

Accessible online at: www.karger.com/ocl
Prof. Sergio Palmeri

Dipartimento di Oncologia

Università di Palermo, Piazza delle Cliniche

IT-90127 Palermo (Italy)

Tel. +39 0916552191, Fax +390916552258, E-Mail s_palmeri@libero.it 
and the mid-1990s, the anthracyclines were the reference chemotherapeutic agents in the treatment of this disease with an overall response rate (ORR) of $35-50 \%$ in firstline and $25-30 \%$ in second-line treatments [1]. Nonetheless, objective tumor responses are usually short-lived, median survival does not exceed 25 months and the toxicity profile is not very suitable for patients with advanced disease. In the past decade, the introduction of two taxanes, paclitaxel and docetaxel, represented an important advance in the treatment of MBC. Docetaxel as a single agent, in previously untreated patients, provides ORR ranging from 40 to $68 \%[2,3]$, while in anthracycline-resistant patients, the ORR is $53-57 \%[4,5]$. Although extremely active in terms of ORR, the 3-week schedule of docetaxel $100 \mathrm{mg} / \mathrm{m}^{2}$ as single agent is associated with grade 3-4 neutropenia in $90-95 \%$ of the cases [6]. Weekly administration of docetaxel, evaluated in phase II studies [6-13], represents an interesting alternative schedule, particularly indicated in the metastatic setting, given the opportunity to reduce chemotherapy-related toxicity (especially hematological toxicity) while preserving its high activity.

Gemcitabine has been shown to be safe and effective when used in MBC. As single agent, both in first- and second-line treatments, it has been reported to yield a 12 $38 \%$ ORR with a good toxicity profile [14-17]. Preclinical evidence of a synergism between gemcitabine and docetaxel on cytotoxicity and apoptosis in breast cancer cells was reported [18]. Due to the activity of the two agents, the different mechanism of action, the nonoverlapping toxicities and the favorable toxicity profile of the weekly schedule, there is a strong rationale to use this drug combination for the treatment of MBC patients, with an attempt to combine the clinical response with the improvement or maintenance of quality of life and prolongation of survival. We have recently carried out a dosefinding study with docetaxel plus gemcitabine on a new weekly schedule (gemcitabine $800 \mathrm{mg} / \mathrm{m}^{2}$ on days 1,8 and 15 every 28 days + docetaxel at 3 escalating dose levels of 30,35 and $40 \mathrm{mg} / \mathrm{m}^{2}$ ) in 18 pretreated MBC patients with the aim to determine the maximum tolerable dose (MTD) of docetaxel and the toxicity patterns of this regimen. The MTD for docetaxel was established at $35 \mathrm{mg} / \mathrm{m}^{2}$. Hematological and nonhematological toxicities were low in number and manageable [19]. With this background, we conducted a multi-institutional phase II study, whose data were partially presented in an abstract form [20], to evaluate the clinical efficacy, the toxicity pattern and the dose-intensity of a new weekly regimen of docetaxel and gemcitabine.

Weekly Docetaxel and Gemcitabine in Metastatic Breast Cancer

\section{Patients and Methods}

Patients with cytologically and histologically confirmed breast carcinoma at the first diagnosis of metastatic disease were enrolled. The presence of measurable disease was requested. Previous hormone therapy for both adjuvant and anti-metastatic purposes was allowed. Previous adjuvant radiotherapy or for advanced breast cancer was permitted, provided the irradiated lesions were not the only site of disease. With regard to adjuvant chemotherapy, if it did not include a taxane, patients could be enrolled independently of the length of time elapsed from the end of adjuvant therapy; if the adjuvant treatment included a taxane, a 12-month interval at the end of chemotherapy was mandatory. To be eligible, patients had to be aged between 18 and 75 years, have a performance status between 0 and 2 on the ECOG scale and a life expectancy of more than 3 months. Other inclusion criteria included: adequate bone marrow [absolute neutrophil count $(\mathrm{ANC}) \geq 1,500 / \mu$ l, platelet count $\geq 120,000 / \mu 1, \mathrm{Hb} \geq 10 \mathrm{~g} / \mathrm{dl}$ ], liver (serum total bilirubin $\leq 2 \mathrm{mg} / \mathrm{dl}$; GOT/GPT $<2 \times$ the upper normal value) and renal functions (serum creatinine $\leq 1.2 \mathrm{mg} / \mathrm{dl}$ ); absence of other concurrent or previous malignant neoplasm, with the exception of adequately controlled in situ uterine carcinoma and/or cutaneous basal cell carcinoma; geographical accessibility to the participating oncology centers and written informed consent. Exclusion criteria: clinically detectable brain metastases, concurrent and uncontrolled cardiovascular, metabolic, renal, neurological or infectious diseases. Previous chemotherapy for metastatic disease, concurrent treatment with other chemotherapeutic, hormonal or immunological antineoplastic agents, and pregnancy also rendered the patient ineligible. The study was approved by an independent ethics committee. Subsequently, an accurate clinical history was taken and all patients underwent a complete clinical examination. Before starting chemotherapy, all eligible patients were extensively staged for accurate definition of disease extension and measurement of disease with two-view chest X-ray, abdomen ultrasound, computed tomography of the involved areas, and bone scan. Complete blood cell counts were performed weekly and routine biochemistry at every cycle. After 3 and 6 cycles, patients underwent re-evaluation of their disease with the same basal staging procedures.

\section{Treatment Schedule}

Patients received docetaxel $35 \mathrm{mg} / \mathrm{m}^{2}$ by intravenous infusion for $60 \mathrm{~min}$ on days 1,8 and 15 , and gemcitabine $800 \mathrm{mg} / \mathrm{m}^{2}$ by intravenous infusion for $30 \mathrm{~min}$ after docetaxel infusion on days 1 , 8 and 15 . The sequence of 3 administrations on days $1,8,15$, followed by a 2 -week rest period, represented a cycle. In order to prevent fluid retention and hypersensitivity reactions, all patients received dexamethasone $8 \mathrm{mg} 12 \mathrm{~h}$ before administration and on days 1 and 2. Antiemetic treatment was administered at the discretion of each researcher. The routine use of prophylactic G-CSF was not allowed; however, investigators were free to employ growth factors according to individual patients' needs in case of neutropenia $(\mathrm{ANC}<900 / \mu \mathrm{l})$ and/or infectious complications. The type of objective response achieved and recorded after the first 3 cycles determined the duration of treatment: in the case of a CR, patients received 3 further cycles up to a maximum of 6 cycles of chemotherapy; in the case of partial tumor regression or stabilization, patients received 3 more cycles and were then re-evaluated for response; treatment continued up to a total of 8 cycles, progression or unacceptable toxicity. If progression of disease occurred, patients 
dropped out of the study and were followed up to record overall survival.

\section{Assessment of Response, Toxicity and Dose Intensity}

Complete response (CR), partial response (PR), stable disease (SD) and progressive disease (PD) were assessed according to the WHO criteria [21]. CR was defined as complete regression of all lesions and signs and symptoms of disease. PR was defined as a reduction $\geq 50 \%$ in the sum of the product of the two principal diameters of all measurable lesions, including partial healing of lytic lesions or reduction in the number of the uptake areas, lasting at least 2 months. SD was considered as a $<50 \%$ reduction or $<25 \%$ increase in the above sum, lasting at least 3 months. PD was defined as an increase $>25 \%$ in the sum of the product of the two principal diameters of all measurable lesions, and/or the appearance of new lesions. Toxicity was assessed at every cycle according to the WHO. If, on the planned day of therapy, $\mathrm{ANC}$ was $<1,500 / \mu 1$ and/or platelet count was less than $100,000 / \mu 1$, chemotherapy was delayed for 1 week; in the case of slow recovery despite delay, subsequent doses of both gemcitabine and docetaxel were reduced by $25 \%$. If grade 2 liver toxicity occurred, docetaxel and gemcitabine dosages were both reduced by $50 \%$; in the case of persistent grade 2 or de novo grade 3 hepatic toxicity, treatment was delayed by 1 week to allow recovery; if no recovery was verified within 2 weeks, treatment was stopped and patients dropped out. In the case of grade 1-2 neurotoxicity, the dose of docetaxel was reduced by $50 \%$ for subsequent administrations, while gemcitabine dosage remained unaltered. If neurotoxicity of more than grade 2 occurred, treatment withdrawal was considered. The actual dose intensity was calculated for docetaxel and gemcitabine using the following formula: dose $(\mathrm{mg}) \times$ number of administrations/total interval between courses (weeks).

\section{Statistical Analysis}

The primary end-point of this phase II study was the evaluation of clinical efficacy in terms of clinical response, survival, time to progression (TTP) and time to treatment failure (TTF); secondary end-points were considered: analysis of toxicity profile and of dose intensity. The study was designed to detect a $60 \%$ ORR applying a two-step minimax design according to Simon. Considering a type 1 error of 0.05 and a type 2 error of 0.20 , at least 8 objective responses had to be recorded in the first cohort of 16 patients in order to proceed to the second step, after which a total of 30 responses had to be achieved in the whole population before being able to reject the hypothesis that the ORR was less than the estimated $60 \%$. A total of 50 assessable patients were to be enrolled in the trial. Duration of CR was calculated from the first assessment of CR until the appearance of PD. Duration of PR or SD was defined from the time of starting chemotherapy until disease progression. TTP was calculated from the date of starting chemotherapy until clinical and/or instrumental evidence of progressive disease, while overall survival was calculated from the date of starting chemotherapy until death or last documented follow-up. TTF was calculated from the date of starting chemotherapy until the date of progression, death (by any cause), adverse event, loss to follow-up, whichever occurred first. The follow-up time was measured from the day of the administration of first the treatment to the last contact or death.

All data concerning TTP, TTF and overall survival were analyzed by computer to generate curves according to the Kaplan and Meier method by the SPSS statistical package (version 8.0, 1997).

\section{Results}

\section{Patients' Characteristics}

Between January 2001 and June 2003, 58 patients with MBC were enrolled into the study. All patients were chemotherapy naive for metastatic disease. Fifty-six $(96.5 \%)$ patients were assessable for response and all for toxicity. Two patients were not assessable for response because they refused to continue therapy. The characteristics of this cohort of patients are summarized in table 1 . The median age was 58.5 years (35-75) and PS according to ECOG was 0 in 32 patients $(55.2 \%), 1$ in $24(41.4 \%)$, 2 in $2(3.4 \%)$. Thirty (52\%) patients had received an anthracycline-based chemotherapy ( 3 in a neoadjuvant and 27 in an adjuvant setting). With regard to the other adjuvant treatments, $2(3 \%)$ patients had received a taxane (paclitaxel). In this group, an adequate interval ( $>12$ months) from the adjuvant treatment, as per protocol, was respected. No patient had received previous docetaxel-containing therapy. Two patients had received adjuvant high-dose chemotherapy plus peripheral blood stem cell reinfusion. Thirty-six (62\%) patients had multiple sites of disease: 15 (26\%) had 2 sites of disease, 21 (36\%) had $>3$ sites of disease. The sites of metastases were: lung in $27(46 \%)$, lymph nodes in $21(36 \%)$, liver in $18(31 \%)$, bone in $20(34 \%)$, pleura in $13(22 \%)$, skin in $12(21 \%)$, breast in $11(19 \%)$, pericardium in $3(5 \%)$, and peritoneum, ovary and adrenal gland in $1(2 \%)$. At least 1 visceral site of metastasis was present in $45(77.6 \%)$ patients.

\section{Response and Survival}

A total of 270 cycles was administered with a median number of 4.5 cycles (1-12) per patient. Planned dose intensity for docetaxel was $26.25 \mathrm{mg} / \mathrm{m}^{2} /$ week and $600 \mathrm{mg} / \mathrm{m}^{2} /$ week for gemcitabine. The median actual dose intensity for docetaxel was 26.25 (13.12-26.25) $\mathrm{mg} / \mathrm{m}^{2} /$ week (100\% of the planned dose) and $600(300$ $600) \mathrm{mg} / \mathrm{m}^{2} /$ week ( $100 \%$ of the planned dose) for gemcitabine. Thirty-eight patients $(65 \%)$ received treatment with a $>90 \%$ dose intensity.

Following the research protocol, we proceeded to the second step of the study after obtaining 8 objective responses in the first group of 16 patients. Among the 56 assessable patients, 9 (16.1\%) achieved a CR, 27 (48.2\%) obtained a PR with an ORR of 64.3\%.Twelve (21.4\%) patients had SD while PD occurred in $8(14.3 \%)$ patients. Patients with CR had a median TTP of 12.3 months (95\% CI: 5.15-19.45); in patients with PR the median TTP was 15.5 months (95\% CI: 9.54-21.46). In patients with SD 
Table 1. Patients' characteristics

\begin{tabular}{|c|c|c|}
\hline Patient characteristics & $\mathrm{n}$ & $\%$ \\
\hline Number of patients enrolled & 58 & 100 \\
\hline Assessable for activity & 56 & 96 \\
\hline Assessable for toxicity & 58 & 100 \\
\hline Age, median (range) & \multicolumn{2}{|c|}{$58.5(35-75)$} \\
\hline \multicolumn{3}{|l|}{ Performance status (ECOG) } \\
\hline 0 & 32 & 55.2 \\
\hline 1 & 24 & 41.4 \\
\hline 2 & 2 & 3.4 \\
\hline \multicolumn{3}{|l|}{ Histological type } \\
\hline Ductal invasive & 40 & 69 \\
\hline Lobular invasive & 7 & 12.1 \\
\hline Medullary & 2 & 3.4 \\
\hline NOS & 9 & 15.5 \\
\hline \multicolumn{3}{|l|}{ Previous treatments } \\
\hline Surgery & 49 & 84 \\
\hline Radiotherapy & 15 & 26 \\
\hline Adjuvant chemotherapy & 42 & 72 \\
\hline Neoadjuvant chemotherapy & 3 & 5 \\
\hline Taxol-containing chemotherapy & 2 & 3 \\
\hline Anthracycline-containing chemotherapy & 30 & 52 \\
\hline High-dose chemotherapy + PBSC & 2 & 3 \\
\hline Hormone therapy adjuvant/first-line & $27 / 6$ & $46 / 10$ \\
\hline Radiotherapy adjuvant/first-line & $15 / 7$ & $26 / 12$ \\
\hline \multicolumn{3}{|l|}{ Metastatic sites } \\
\hline 1 & 22 & 38 \\
\hline 2 & 15 & 26 \\
\hline$\geq 3$ & 21 & 36 \\
\hline \multicolumn{3}{|l|}{ Sites of disease } \\
\hline Lung & 27 & 46 \\
\hline Nodes & 21 & 36 \\
\hline Bone & 20 & 34 \\
\hline Liver & 18 & 31 \\
\hline Pleura & 13 & 22 \\
\hline Skin & 12 & 21 \\
\hline Breast & 11 & 19 \\
\hline Pericardium & 3 & 5 \\
\hline Ovary & 1 & 2 \\
\hline Peritoneum & 1 & 2 \\
\hline Adrenal gland & 1 & 2 \\
\hline \multicolumn{3}{|l|}{ Cycles administered } \\
\hline Median (min-max) & 4.5 & \\
\hline Total & 270 & \\
\hline
\end{tabular}

the median TTP was 9.77 months (95\% CI: 2.25-17.28). After a median follow-up of 10.6 months, 15 patients died (all for tumor-related causes) and 43 patients (74.1\%) are still alive at the cut-off date of 36 months; 24 patients experienced PD. The median survival was 22.10 months (95\% CI: 15.53-28.67). The median survival for patients with CR was 22.27 months (95\% CI: 13.84-30.70). Patients who achieved a PR had a median survival of 29.30 months (95\% CI: 18.74-30.61). In patients with SD me-
Table 2. Response and survival

\begin{tabular}{|c|c|c|c|c|c|c|}
\hline \multirow{2}{*}{$\begin{array}{l}\text { Objective } \\
\text { response }\end{array}$} & \multicolumn{2}{|c|}{ Patients } & \multicolumn{2}{|c|}{ TTP, months } & \multicolumn{2}{|c|}{ Survival, months } \\
\hline & $\mathrm{n}$ & $\%$ & median & $95 \% \mathrm{CI}$ & median & $95 \% \mathrm{CI}$ \\
\hline CR & 9 & 16.1 & 12.3 & $5.15-19.45$ & 22.27 & $13.84-30.70$ \\
\hline PR & 27 & 48.2 & 15.5 & $9.54-21.46$ & 29.30 & $18.74-30.61$ \\
\hline SD & 12 & 21.4 & 9.77 & $2.25-17.28$ & 24.57 & $16.43-32.70$ \\
\hline PD & 8 & 14.3 & 2.7 & $1.42-3.98$ & 7.43 & $3.96-7.63$ \\
\hline
\end{tabular}

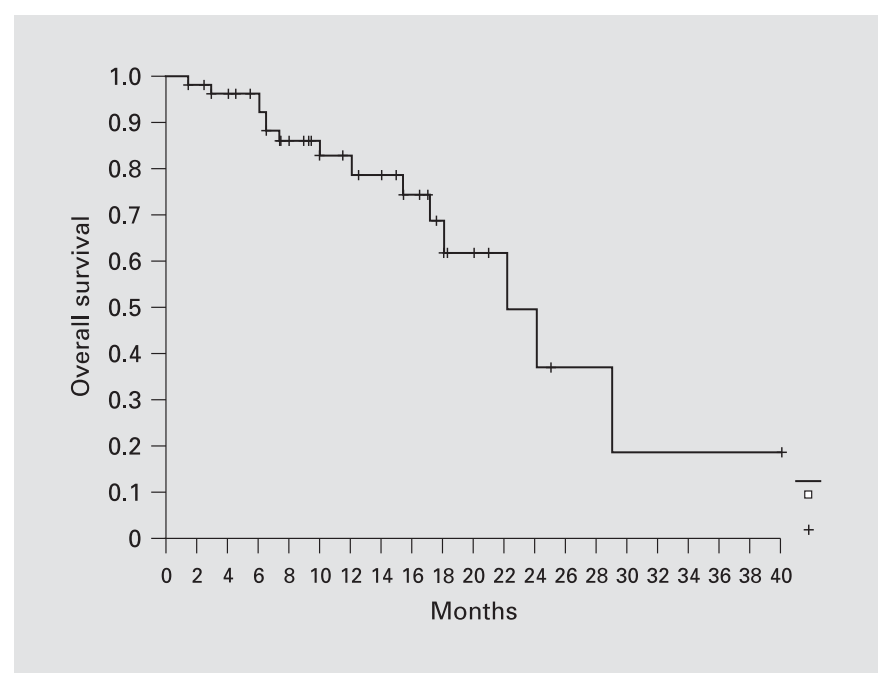

Fig. 1. Kaplan-Meier curve of overall survival. The median survival was 22.10 months (95\% CI: 15.53-28.67).

dian survival was 24.57 months (95\% CI: 16.43-32.70). The median survival in patients who experienced PD was 7.43 months (95\% CI: 3.96-7.63). Objective response and survival data are reported in table 2. The Kaplan-Meier curve of overall survival is represented in figure 1 . The median TTP was 13.6 months (95\% CI: 10.71-16.49). The median TTF was: 8.60 months $(95 \%$ CI: $4.79-$ 12.41).

\section{Compliance to Treatment and Toxicity}

Treatment discontinuation occurred in 2 patients for refusal. The most common hematological toxicity was neutropenia, which occurred in 28 patients $(48.3 \%)$ but grade $3-4$ in only 8 patients (14\%). No case of febrile neutropenia was reported. Twenty patients $(34.5 \%)$ experienced anemia, grade 3 in 2 patients (3.4\%). Grade 3 thrombocytopenia was registered in 4 patients $(6.9 \%)$. Hematological toxicity is reported in table 3. 
Table 3. Hematological toxicity (assessable patients: $n=58$ )

\begin{tabular}{llrc}
\hline \multirow{2}{*}{$\begin{array}{l}\text { Type } \\
\text { (assessable patients = 58) }\end{array}$} & Grade & \multicolumn{2}{c}{ Patients } \\
\cline { 3 - 4 } & & $\mathrm{n}$ & $\%$ \\
\hline Neutropenia & $\mathrm{G} 1 / \mathrm{G} 2$ & 20 & 34.5 \\
& $\mathrm{G} 3 / \mathrm{G} 4$ & 8 & 13.8 \\
\hline Anaemia & $\mathrm{G} 1 / \mathrm{G} 2$ & 18 & 31 \\
& $\mathrm{G} 3 / \mathrm{G} 4$ & 2 & 3.4 \\
\hline Thrombocytopenia & $\mathrm{G} 1 / \mathrm{G} 2$ & 19 & 32.7 \\
& $\mathrm{G} 3 / \mathrm{G} 4$ & 4 & 6.9 \\
\hline
\end{tabular}

With regard to nonhematological toxicity, alopecia was the most common: it occurred in $20(34.5 \%)$ patients, but only 5 patients $(8.6 \%)$ experienced grade 3 alopecia. Asthenia was registered in $13(22.4 \%)$ patients but was of grade 3 in only 1 case (1.7\%). Twelve patients (20.6\%) experienced nausea/vomiting, mostly of grade 1-2 $(18.9 \%)$. Mild hepatic toxicity occurred in 7 patients $(12 \%)$. With respect to grade 3-4 nonhematological toxicities, the most frequent were: alopecia as previously cited, diarrhea in $3(5 \%)$ patients (grade 3 in 2 patients and grade 4 in 1 patient) and stomatitis in $2(4 \%)$ cases (grade 3 in 1 patient and grade 4 in 1 patient). No case of fluid retention syndrome was seen. No patient experienced eye tearing toxicity (table 4). There was no treatment-related death. The addition of gemcitabine and/or the length of treatment did not affect the toxicity profile.

\section{Discussion}

The difficulties which medical oncologists have in finding an optimal treatment for $\mathrm{MBC}$, still an incurable illness, are witnessed by the large amount of studies performed in this area in which it is necessary to combine the need for effective therapies with the goal of the improving quality of life and survival.

Docetaxel is a highly active agent in advanced breast cancer. It has demonstrated a superior activity when compared both to single agent doxorubicin [22] or paclitaxel [23] and polichemotherapy as mitomycin C plus vinblastine [24] or methotrexate plus 5-fluorouracil [25].

Although extremely active, the 3-week schedule of docetaxel $100 \mathrm{mg} / \mathrm{m}^{2}$ as single agent is associated with a high incidence of myelosuppression [6]. Weekly administration of docetaxel has an efficacy at least comparable with the standard 21-day administration with lower my-
Table 4. Non-haematological toxicity (assessable patients: $n=58$ )

\begin{tabular}{|c|c|c|c|}
\hline \multirow[t]{2}{*}{ Type } & \multirow[t]{2}{*}{ Grade } & \multicolumn{2}{|c|}{ Patients } \\
\hline & & $\mathrm{n}$ & $\%$ \\
\hline \multirow[t]{2}{*}{ Nausea/vomiting } & $\mathrm{G} 1 / \mathrm{G} 2$ & 11 & 18.9 \\
\hline & $\mathrm{G} 3 / \mathrm{G} 4$ & 1 & 1.7 \\
\hline \multirow[t]{2}{*}{ Diarrhea } & $\mathrm{G} 1 / \mathrm{G} 2$ & 4 & 6.9 \\
\hline & $\mathrm{G} 3 / \mathrm{G} 4$ & 3 & 5.2 \\
\hline \multirow[t]{2}{*}{ Stomatitis } & $\mathrm{G} 1 / \mathrm{G} 2$ & 4 & 6.9 \\
\hline & $\mathrm{G} 3 / \mathrm{G} 4$ & 2 & 3.4 \\
\hline \multirow[t]{2}{*}{ Renal } & $\mathrm{G} 1 / \mathrm{G} 2$ & 1 & 1.7 \\
\hline & $\mathrm{G} 3 / \mathrm{G} 4$ & - & - \\
\hline \multirow[t]{2}{*}{ Hepatic } & $\mathrm{G} 1 / \mathrm{G} 2$ & 7 & 12.1 \\
\hline & $\mathrm{G} 3 / \mathrm{G} 4$ & - & - \\
\hline \multirow[t]{2}{*}{ Alopecia } & $\mathrm{G} 1 / \mathrm{G} 2$ & 15 & 25.9 \\
\hline & $\mathrm{G} 3 / \mathrm{G} 4$ & 5 & 8.6 \\
\hline \multirow[t]{2}{*}{ Fever } & $\mathrm{G} 1 / \mathrm{G} 2$ & 8 & 13.8 \\
\hline & $\mathrm{G} 3 / \mathrm{G} 4$ & - & - \\
\hline \multirow[t]{2}{*}{ Cardiac } & $\mathrm{G} 1 / \mathrm{G} 2$ & 2 & 3.4 \\
\hline & $\mathrm{G} 3 / \mathrm{G} 4$ & - & - \\
\hline \multirow[t]{2}{*}{ Neurotoxicity } & $\mathrm{G} 1 / \mathrm{G} 2$ & 3 & 5.2 \\
\hline & $\mathrm{G} 3 / \mathrm{G} 4$ & 1 & 1.7 \\
\hline \multirow[t]{2}{*}{ Asthenia } & $\mathrm{G} 1 / \mathrm{G} 2$ & 12 & 20.7 \\
\hline & $\mathrm{G} 3 / \mathrm{G} 4$ & 1 & 1.7 \\
\hline \multirow[t]{2}{*}{ Skin } & G1/G2 (nail changes) & 2 & 3.4 \\
\hline & $\mathrm{G} 3 / \mathrm{G} 4$ & 1 & 1.7 \\
\hline Flu-like syndrome & & 1 & 1.7 \\
\hline
\end{tabular}

elotoxicity $[6-13,26]$. The better toxicity profile of weekly docetaxel makes it particularly suitable for combination with other active drugs as gemcitabine in MBC patients.

The combination of docetaxel and gemcitabine as firstand second-line therapy for $\mathrm{MBC}$ has been evaluated in phase II trials [27-36]. Mavroudis et al. [27] enrolled 52 patients previously treated for metastatic disease. Their patients received gemcitabine $900 \mathrm{mg} / \mathrm{m}^{2}$ i.v. on days 1 and 8 and docetaxel $100 \mathrm{mg} / \mathrm{m}^{2}$ on day 8 , every 3 weeks and prophylactic G-CSF from the 9th to the 15th day. The ORR was $54 \%$, with $14 \%$ CR and $40 \%$ PR. Four patients, who had PD after a paclitaxel or docetaxel monotherapy, achieved a PR after treatment with the combination of docetaxel and gemcitabine. The median duration of response was 3.6 months and the median TTP 8 months. Regarding the hematological toxicity, neutropenia of grade 3-4 occurred in 29\% of patients despite the 
Table 5. Phase II studies with gemcitabine-docetaxel combination in MBC

\begin{tabular}{|c|c|c|c|c|c|c|}
\hline $\begin{array}{l}\text { Author and year } \\
\text { of publication }\end{array}$ & $\begin{array}{l}\text { Pa- } \\
\text { tients }\end{array}$ & Prior therapy & Schedule & $\begin{array}{l}\text { ORR } \\
\%\end{array}$ & $\begin{array}{l}\text { TTP } \\
\text { months }\end{array}$ & Toxicities, $\%$ \\
\hline $\begin{array}{l}\text { Mavroudis et al. [27] } \\
1999\end{array}$ & 52 & $\begin{array}{l}\text { anthracyclines } \\
100 \%\end{array}$ & $\begin{array}{l}\mathrm{G} 900 \mathrm{mg} / \mathrm{m}^{2} 1,8+\mathrm{T} 100 \mathrm{mg} / \mathrm{m}^{2} \\
8 \mathrm{q} 21\end{array}$ & 54 & 8 & $\begin{array}{l}\text { neutropenia } G 3 / 4=29 \\
\text { thrombocytopenia } G 3 / 4=21\end{array}$ \\
\hline $\begin{array}{l}\text { Fountzilas et al. [31] } \\
2000\end{array}$ & 39 & $\begin{array}{l}\text { anthracyclines } \\
100 \%\end{array}$ & $\begin{array}{l}\mathrm{G} 1,000 \mathrm{mg} / \mathrm{m}^{2} 1,8+\mathrm{T} 75 \mathrm{mg} / \mathrm{m}^{2} \\
1 \mathrm{q} 21\end{array}$ & 36 & 7 & $\begin{array}{l}\text { neutropenia G3/4 = } 49 \\
\text { FN = } 18 \\
\text { alopecia G3 = } 77.5\end{array}$ \\
\hline $\begin{array}{l}\text { Laufman et al. [32] } \\
2001\end{array}$ & 39 & $\begin{array}{l}\text { anthracyclines } \\
85 \%\end{array}$ & $\begin{array}{l}\mathrm{G} 800 \mathrm{mg} / \mathrm{m}^{2} 1,8,15+\mathrm{T} 100 \mathrm{mg} / \mathrm{m}^{2} 1 \\
\mathrm{q} 28\end{array}$ & 79 & 7.6 & $\begin{array}{l}\text { neutropenia } \mathrm{G} 3 / 4=39 \\
\mathrm{FN}=7.7 \\
\text { alopecia }=100\end{array}$ \\
\hline $\begin{array}{l}\text { Kornek et al. [33] } \\
2002\end{array}$ & 52 & $\begin{array}{l}\text { anthracyclines } \\
19 \%\end{array}$ & $\begin{array}{l}\mathrm{G} 1,500 \mathrm{mg} / \mathrm{m}^{2} 1,15+\mathrm{T} 50 \mathrm{mg} / \mathrm{m}^{2} \\
1,15 \mathrm{q} 28\end{array}$ & $\begin{array}{l}60.5^{\mathrm{a}} \\
43^{\mathrm{b}}\end{array}$ & $\begin{array}{l}8.5^{\mathrm{a}} \\
6.6^{\mathrm{b}}\end{array}$ & $\begin{array}{l}\text { neutropenia } G 3 / 4=29 \\
\text { alopecia } G 3=35\end{array}$ \\
\hline $\begin{array}{l}\text { Garle et al. [30] } \\
2003\end{array}$ & 48 & $\begin{array}{l}\text { anthracyclines } \\
33 \%\end{array}$ & $\begin{array}{l}\mathrm{G} 2,500 \mathrm{mg} / \mathrm{m}^{2} 1,14+\mathrm{T} 65 \mathrm{mg} / \mathrm{m}^{2} \\
1,14 \mathrm{q} 14\end{array}$ & 71 & 9.1 & $\begin{array}{l}\text { neutropenia } G 3 / 4=44 \\
F N=4 \\
\text { fatigue } G 3 / 4=15\end{array}$ \\
\hline $\begin{array}{l}\text { Alexopoulos et al. } \\
{[34], 2004}\end{array}$ & 50 & $\begin{array}{l}\text { docetaxel } \\
100 \%\end{array}$ & $\begin{array}{l}\mathrm{G} 900 \mathrm{mg} / \mathrm{m}^{2} 1,8+\mathrm{T} 100 \mathrm{mg} / \mathrm{m}^{2} \\
8 \mathrm{q} 21\end{array}$ & 46 & 7.5 & neutropenia G3 = 24 \\
\hline $\begin{array}{l}\text { Pelegri et al. [28] } \\
2004\end{array}$ & 71 & $\begin{array}{l}\text { anthracyclines } \\
28 \%\end{array}$ & $\begin{array}{l}\mathrm{G} 2,500 \mathrm{mg} / \mathrm{m}^{2} 1+\mathrm{T} 65 \mathrm{mg} / \mathrm{m}^{2} \\
1 \mathrm{q} 14\end{array}$ & 66 & NR & neutropenia $\mathrm{G} 3 / 4=45$ \\
\hline $\begin{array}{l}\text { Brandi et al. [35] } \\
2004\end{array}$ & 53 & $\begin{array}{l}\text { anthracyclines } \\
100 \%\end{array}$ & $\begin{array}{l}\mathrm{G} 1,000 \mathrm{mg} / \mathrm{m}^{2} 1,8+\mathrm{T} 80 \mathrm{mg} / \mathrm{m}^{2} \\
8 \mathrm{q} 21\end{array}$ & 53 & 7.5 & $\begin{array}{l}\text { neutropenia } G 3 / 4=43 \\
\text { anemia } G 3 / 4=8\end{array}$ \\
\hline $\begin{array}{l}\text { Slee et al. [36] } \\
2004\end{array}$ & 26 & $\begin{array}{l}\text { anthracyclines } \\
100 \%\end{array}$ & $\begin{array}{l}\mathrm{G} 1,000 \mathrm{mg} / \mathrm{m}^{2} 1,8+\mathrm{T} 75 \mathrm{mg} / \mathrm{m}^{2} \\
8 \mathrm{q} 21\end{array}$ & 61 & 7.7 & $\begin{array}{l}\text { leucopenia } G 3 / 4=23 / 184 \\
\text { cycles }\end{array}$ \\
\hline Palmeri, present study & 58 & $\begin{array}{l}\text { anthracyclines } \\
52 \%\end{array}$ & $\begin{array}{l}\mathrm{G} 800 \mathrm{mg} / \mathrm{m}^{2} 1,8,15+\mathrm{T} 35 \mathrm{mg} / \mathrm{m}^{2} 1, \\
8,15 \mathrm{q} 28\end{array}$ & 64.3 & 13.6 & $\begin{array}{l}\text { neutropenia } \mathrm{G} 3 / 4=13.8 \\
\text { diarrhea } \mathrm{G} 3 / 4=5.2\end{array}$ \\
\hline
\end{tabular}

$\mathrm{G}=$ Gemcitabine; $\mathrm{T}=$ docetaxel $; \mathrm{NR}=$ not reported $; \mathrm{FN}=$ febrile neutropenia.

${ }^{\text {a }}$ First-line treatment.

b Second-line treatment.

prophylactic use of G-CSF and thrombocytopenia of grade $3-4$ was registered in $21 \%$ of patients. The median dose intensity was 26.5 and $513 \mathrm{mg} / \mathrm{m}^{2} /$ week for docetaxel and gemcitabine, respectively.

A regimen of docetaxel and gemcitabine every 2 weeks was used as first line therapy in 3 phase II trials. Pelegri et al. [28] treated 71 patients with docetaxel $65 \mathrm{mg} / \mathrm{m}^{2}$ and gemcitabine $2,500 \mathrm{mg} / \mathrm{m}^{2}$ on day 1 of a 14-day cycle. An objective response rate of $66 \%$ was registered. Grade 3-4 neutropenia occurred in $45 \%$ of patients. In the study of Mavroudis et al. [27], 47 patients (37 assessable for response) were enrolled to receive docetaxel $65 \mathrm{mg} / \mathrm{m}^{2}$ and gemcitabine $1,500 \mathrm{mg} / \mathrm{m}^{2}$ on day 1 every 2 weeks. The intent-to-treat ORR was $75.6 \%$. Grade 3-4 neutropenia was registered in $14(30 \%)$ patients with febrile neutropenia in $2(5 \%)$ cases [29]. Garle et al. [30] adminis- tered docetaxel $65 \mathrm{mg} / \mathrm{m}^{2}$ and gemcitabine $2,500 \mathrm{mg} / \mathrm{m}^{2}$ on day 1 of a 14-day cycle to 48 patients obtaining an objective response rate of $71 \%$. In this study grade 3-4 neutropenia was also registered in $44 \%$ of patients. Grade 3-4 fatigue ( $15 \%$ of cases) was the most frequent nonhematological toxicity. For comparison with the present study, table 5 lists previous studies with the gemcitabinedocetaxel combination in MBC.

In our dose-finding study [19], 18 heavily pretreated patients received 3 escalating weekly doses of docetaxel $\left(30,35\right.$ and $\left.40 \mathrm{mg} / \mathrm{m}^{2}\right)$ with a weekly fixed dose of gemcitabine $800 \mathrm{mg} / \mathrm{m}^{2}$ on days 1,8 and 15 of a 28-day cycle. The MTD for docetaxel was reached at the $40 \mathrm{mg} / \mathrm{m}^{2}$ dose and the recommended dose for subsequent phase II studies was established at the $35 \mathrm{mg} / \mathrm{m}^{2}$ dose. Leucopenia was prevalent at the highest dose of $40 \mathrm{mg} / \mathrm{m}^{2}$. The promising 
activity data obtained $(\mathrm{ORR}=58 \%)$ in a heavily pretreated population of patients, even if small, encouraged the exploration of this innovative schedule in a phase II setting.

The present study focuses on a new combination therapy administered weekly as first line treatment in MBC patients. At least 1 visceral site of metastasis was present in $45(77.6 \%)$ patients. In the 56 assessable patients, the ORR was $64.3 \%$ with 9 patients (16.1\%) achieving a CR, $27(48.2 \%)$ a PR response and $12(21.4 \%)$ patients with SD. The median survival was 22.10 months $(95 \% \mathrm{CI}$ : 15.53-28.67) with $43(74.1 \%)$ patients still alive at the cut-off date of 36 months. Noteworthily, the TTP was 13.6 months (CI 95\%: 10.71-16.49). The median TTF was: 8.60 months (95\% CI: 4.79-12.41). At the time of cutting off, 24 patients experienced PD. Another remarkable point is the length of response in patients with SD: in fact, in this subgroup, the median duration of response was 19.27 months. Furthermore, the median survival of patients who achieved PR was 29.30 months.
The data from this study seem to confirm that the combination of docetaxel and gemcitabine is active in advanced breast cancer. This weekly schedule seems to be active and well tolerated, the median actual dose intensity being $26.25 \mathrm{mg} / \mathrm{m}^{2} /$ week ( $100 \%$ of the planned dose) for docetaxel and $600 \mathrm{mg} / \mathrm{m}^{2} /$ week (100\% of the planned dose) for gemcitabine.

These results, with 56 assessable patients, are in agreement with other published studies. Grade 3-4 neutropenia occurred in only 8 patients (14\%). Regarding nonhematological toxicity, grade 3 alopecia was experienced by only 5 cases (9\%). No case of fluid retention syndrome was seen. Furthermore, this schedule is manageable in an outpatient setting.

The need to perform adequately designed and sized phase III trials is strongly felt in order to confirm the promising results of this study, considering two study populations: patients who have received prior anthracycline-containing therapy and anthracycline-naive patients.

\section{References}

1 Henderson IC: Chemotherapy for metastatic disease; in Harris JR, Hellman S, Henderson JC, et al (eds): Breast Diseases. Philadelphia, Lippincott, 1991, pp 604-665.

2 Valero V: Docetaxel as single-agent therapy in metastatic breast cancer: Clinical efficacy. Semin Oncol 1997;24:S13-S18.

3 Cortes JE, Pazdur R: Docetaxel. J Clin Oncol 1995;13:2643-2655.

4 Ravdin PM, Burris HA 3rd, Cook G, Eisenberg P, Kane M, Bierman WA, Mortimer J, Genevois E, Bellet RE: Phase II trial of docetaxel in advanced anthracycline-resistant or anthracenedione-resistant breast cancer. J Clin Oncol 1995;13:2879-2885.

5 Valero V, Holmes FA, Walters RS, Theriault RL, Esparza L, Fraschini G, Fonseca GA, Bellet RE, Buzdar AU, Hortobagyi GN: Phase II trial of docetaxel: A new, highly effective antineoplastic agent in the management of patients with anthracycline-resistant metastatic breast cancer. J Clin Oncol 1995;13:2886-2894.

6 Burstein HJ, Manola J, Younger J, Parker LM, Bunnell CA, Scheib R, Matulonis UA, Garber JE, Clarke KD, Shulman LN, Winer EP: Docetaxel administered on a weekly basis for metastatic breast cancer. J Clin Oncol 2000;18: 1212-1219.

7 Climent MA, Ruiz A, Llombart-Cussac A, Fernandez-Martos C, Poveda A, Dorta J, Guillem $\mathrm{V}$ : Weekly docetaxel in patients with advanced malignancies. Toxicity profile and activity results (abstract 453). Proc Am Soc Clin Oncol 1999; 18:119
8 Loeffler TM, Droege C, Hausamen TU, et al: Dose-dense weekly docetaxel (Taxotere) in metastatic breast cancer (abstract). Breast Cancer Res Treat 1999;57:125.

9 Ramos M, Gonzalez-Ageitos A, Vicente J: Weekly docetaxel (D) for metastatic breast cancer (MBC) progressing after anthracycline treatment (abstract 445). Proc Am Soc Clin Oncol 2000; 19:155.

10 Hainsworth JD, Burris HA 3rd, Yardley DA, Bradof JE, Grimaldi M, Kalman LA, Sullivan T, Baker M, Erland JB, Greco FA: Weekly docetaxel in the treatment of elderly patients with advanced breast cancer: A Minnie Pearl Cancer Research Network phase II trial. J Clin Oncol 2001;19:3500-3505.

11 Stemmler HJ, Gutschow K, Sommer H, Malekmohammadi M, Kentenich CH, Forstpointner R, Geuenich S, Bischoff J, Hiddemann W, Heinemann V: Weekly docetaxel (taxotere) in patients with metastatic breast cancer. Ann Oncol 2001;12:1393-1398.

12 Aihara T, Kim Y, Takatsuka Y: Phase II study of weekly docetaxel in patients with metastatic breast cancer. Ann Oncol 2002;23:286-292.
13 Climent MA, Tabernero J, Albanell J, Lluch A, Vermorken J, Barnadas A, Anton A, Laurent C, Mayordomo JI, Vazquez-Estevez S, Constenla M, Dirix LY, Losa I, Tisaire JL, Guillem V, Garcia-Conde J, Baselga J: Preliminary results of a phase II randomized trial of docetaxel (taxotere) as a single agent chemotherapy (CT) administered weekly or 3-weekly in patients (pts) with metastatic breast cancer (MBC) (abstract 205). Proc Am Soc Clin Oncol 2002;21:52a.

14 Silvestris N, Di Cosimo S, Locopo N, D’Aprile M, Lorusso V: Rationale for the use of gemcitabine in treating breast cancer. Trends Med 2003; 3:163-173.

15 Carmichael J, Possinger K, Philip P, Beykirch M, Kerr H, Walling J, Harris AL: Advanced breast cancer :a phase II trial with gemcitabine. J Clin Oncol 1995;13:2731-2736.

16 Blackstein M, Vogel CL, Ambinder R, Cowan J, Iglesias J, Melemed A: Gemcitabine as firstline therapy in patients with metastatic breast cancer: A phase II trial. Oncology 2002;62:28.

17 Spielmann M, Llombart-Cussac A, Kalla S, Espie M, Namer M, Ferrero JM, Dieras V, Fumoleau P, Cuvier C, Perrocheau G, Ponzio A, Kayitalire L, Pouillart P: Single-agent gemcitabine is active in previously treated metastatic breast cancer. Oncology 2001;60:303-307. 
18 Ferrari S, Danova M, Palmeri S, Brugnatelli S, Tamburo De Bella M, Porta C, Riccardi A: Apoptosis and cell cycle perturbation induced by docetaxel + gemcitabine in MCF7 breast cancer cells (abstract 330). Proc 25th Annu Meet Ital Assoc Med Oncol, Rome, 1999, p 109.

19 Brugnatelli S, Danova M, Tamburo De Bella M, Vaglica M, Manuguerra G, Riccardi A, Palmeri S: Weekly administration of gemcitabine plus docetaxel in patients with advanced breast cancer: A phase 1 study. Oncology 2002;62:33-38.

20 Palmeri S, Vaglica M, Accurso V, Gebbia V, Vassallo E, Danova M, Vetri G, Farris A, Mangiameli A, Manuguerra G, Filippelli G, Lorusso V: Weekly docetaxel (doc) + gemcitabine (gem) as first line therapy for advanced breast cancer (ABC): A multicenter phase II study (abstract 1991). Proc Am Soc Clin Oncol 2002; 21:456.

21 Miller AB, Hoogstraten B, Staquet M, et al: Reporting results of cancer treatment. Cancer 1981;47:207-214.

22 Chan S, Friedrichs K, Noel D, Pinter T, Van Belle S, Vorobiof D, Duarte R, Gil Gil M, Bodrogi I, Murray E, Yelle L, von Minckwitz G, Korec S, Simmonds P, Buzzi F, Gonzalez Mancha R, Richardson G, Walpole E, Ronzoni M, Murawsky M, Alakl M, Riva A, Crown J for the 303 Study Group: Prospective randomized trial of docetaxel versus doxorubicin in patients with metastatic breast cancer. J Clin Oncol 1999; 17:2341-2354.

23 Ravdin P, Erban J, Overmoyer B, Budd GT, Hutchins L, Lower E, Laufman L, Sundaram $\mathrm{S}$, Urba W, Olsen S, Meyers ML, Jones S: Phase III comparison of docetaxel (D) and paclitaxel $(\mathrm{P})$ in patients with metastatic breast cancer (MBC) (abstract 670). ECCO 12, Eur J Cancer 2003;1(suppl 5):S201.

24 Nabholtz JM, Senn HJ, Bezwoda WR, Melnychuk D, Deschenes L, Douma J, Vandenberg TA, Rapoport B, Rosso R, Trillet-Lenoir V, Drbal J, Molino A, Nortier JWR, Richel DJ, Nagykalnai T, Siedlecki P, Wilking N, Genot JY, Hupperets PSGJ, Pannuti F, Skarlos D, Tomiak EM, Murawsky M, Alakl M, Riva A and Aapro M for the 304 Study Group: Prospective randomized trial of docetaxel versus mitomycin $\mathrm{C}$ plus vinblastine in patients with metastatic breast cancer progressing despite previous anthracycline-containing chemotherapy. J Clin Oncol 1999; 17:1413-1424.
25 Sjostrom J, Blomqvist C, Mouridsen H, Pluzanska A, Ottosson-Lonn S, Bengtsson N-O, Ostenstad B, Mjaaland I, Palm-Sjovall M, Wist E, Valvere V, Anderson H, Bergh J: Docetaxel compared with sequential methotrexate and 5fluorouracil in patients with advanced breast cancer after anthracycline failure: A randomised phase III study with crossover on progression by the Scandinavian Breast Group. Eur J Cancer 1999;35:1194-1201.

26 Zimatore M, Danova M, Vassallo E, Porta C, Macaluso MC, Schittone L, Riccardi A, Palmeri S: Weekly taxanes in metastatic breast cancer (review). Oncol Rep 2002;9:10471052.

27 Mavroudis D, Malamos N, Alexapoulos A, Kourousis Ch, Agelaki S, Sarra E, Potamianou A, Kosmas Ch, Rigatos G, Giannakakis Th, Kalbakis K, Apostolaki F, Vlachonicolis J, Kakolyris S, Samonis G, Georgoulias V: Salvage chemotherapy in anthracycline-pretreated patients with docetaxel and gemcitabine: A multicenter phase II trial. Ann Oncol 1999;10: 211-215.

28 Pelegri A, Calvo L,Mayordomo JI, Anton A Florian J, Vazquez S, Arcusa A, Martin-Richard M, Bayo JL, Virizuela J, Carrasco E, Anton A: Gemcitabine and docetaxel given every 2 weeks as first-line therapy for metastatic breast cancer (MBC): Preliminary results from a phase II trial. Semin Oncol 2004;31(suppl 5):20-24.

29 Mavroudis D, Malamos N, Polyzos K, Kalbakis K, Karyda E, Alexapoulos A, Cristophylakis C, Tzaninis D, Kouroussis C, Agelaki S: A multicenter phase II study of docetaxel plus gemcitabine biweekly administration as first line treatment in patients with metastatic breast cancer (MBC) (abstract 259). Proc Am Soc Clin Oncol 2003;22:65.
30 Garle PA, Calvo L, Mayordomo J I, Anton A, Florian J, Vazquez S, Arcusa A, Martin-Richard M, Bayo JL, Carrasco E: Gemcitabine and docetaxel given every other week as firstline therapy for metastatic breast cancer (MBC): Final results of a phase II study conducted within the Breast Cancer Investigation Spanish Group (GEICAM) (abstract 201). Proc Am Soc Clin Oncol 2003;22:50.

31 Fountzilas G, Nicolaides C, Bafaloukos D, Kalogera-Fountzila A, Kalofonos H, Samelis G, Aravantinos G, Pavlidis N: Docetaxel and Gemcitabine in anthracycline-resistant advanced breast cancer: A Hellenic Cooperative Oncology Group phase II study. Cancer Invest 2000; 18:503-509.

32 Laufman LR, Spiridonidis CH, Pritchard J, Roach R, Zangmeister J, Larrimer N, Moore T, Segal M, Jones J, Patel T, Gutterman L, Carman L, Colborn D, Kuebler JP: Monthly docetaxel and weekly gemcitabine in metastatic breast cancer: A phase II trial. Ann Oncol 2001;12:1259-1264.

33 Kornek GV, Haider K, Kwasny W, Raderer M, Schull B, Payrits T, Depisch D, Kovats E, Lang F, Scheithauer W: Treatment of advanced breast cancer with docetaxel and gemcitabine with and without human granulocyte colonystimulating factor. Clin Cancer Res 2002;8: 1051-1056.

34 Alexopoulos A, Tryfonopoulos D, Karamouzis MV, Gerasimidis G, Karydas I, Kandilis K, Stavrakakis J, Stavrinides H, Georganta C, Ardavanis A, Rigatos G: Evidence for in vivo synergism between docetaxel and gemcitabine in patients with metastatic breast cancer. Ann Oncol 2004; 15:95-99.

35 Brandi M, Vici P, Lopez M, Valerio MR, Giotta F, Gebbia N, Schittulli F, Colucci G; Gruppo Oncologico Italia Meridionale: novel association with gemcitabine and docetaxel as salvage chemotherapy in metastatic breast cancer previously treated with anthracyclines: results of a multicenter phase II study. Semin Oncol 2004;31(suppl 5):13-19.

36 Slee PH, De Jong RS, Honkoop Arodenburg C, Rooda SE, Coenen J, De Jong PC, Douma J: Combination chemotherapy with docetaxel and gemcitabine in anthracycline pretreated patients with metastatic breast cancer (MBC) (abstract 792). Proc Am Soc Clin Oncol 2004; 23:145. 
Copyright: S. Karger AG, Basel 2005. Reproduced with the permission of S. Karger AG, Basel. Further reproduction or distribution (electronic or otherwise) is prohibited without permission from the copyright holder. 